\title{
FIQH PROGRESSIVE-ECONOMICS IJTIHAD PARADIGM IN INDONESIA
}

\author{
Moh. Dahlan \\ Lecturer of IAIN Bengkulu \\ Email:drdahlan@yahoo.co.id
}

\begin{abstract}
Abstrak : Wacana fiqih moderat dan toleran sangat dibutuhkan untuk mengkanter wacana fiqih radikal dan ekslusif yang mengalami perkembangan pada dekade terakhir ini. Oleh sebab itu, pembangunan ijtihad fiqih progresif-kontekstual akan memberikan sumbangan penting untuk membendung arus gerakan radikalisme dan tindakan terorisme yang memiliki jaringan internasional. Hal ini penting bagi umat Islam karena fiqih menjadi pondasi dasar dalam membangun perilaku empiris, sehingga dengan adanya paradigma ijtihad fiqih progresif-kontekstual akan mendorong lahirnya wacana fiqih alternatif yang mampu mendorong kehidupan umat yang harmonis, moderat dan toleran. Dengan demikian, pemberlakuan fiqih tidak mesti dapat menimbulkan diskriminasi sebagaimana dugaan sementara kaum sekularis tetapi justru dapat memberikan sumbangan positif dalam pembangunan kemaslahatan umat manusia baik di kalangan umat Islam maupun umat non-Islam jika diterapkan secara progresif dan kontekstual.
\end{abstract}

Kata kunci: ijtihad, fiqih, progresif, dan kontekstual.

\section{Foreword}

The reform era, the era after the fall of New Order government, has created a new structure in the life order of society, nation and state. The reform era has produced a high commitment to the implementation of a substantive democratic system characterized by freedom of expression and tight control over the government. Although, the democracy has not been accompanied by a high awareness of the importance of morality or ethics of civilized life. Thus, many deviations are still found in various political activities, bureaucracy, social and economic.Likewise, the freedom also has created conservatism and liberalism in religious life. ${ }^{1}$ Masykuri Abdillah expalins:

\footnotetext{
${ }^{1}$ Masykuri Abdillah, "Kontribusi Kajian Islam Dalam Mewujudkan Masyarakat Yang Beradab", Paper di sampaikan dalam Annual Conference on Islamic Studies (ACIS), yang diselenggarakan oleh Direktorat Perguruan Tinggi
}

the freedom in the context of religious life creates the opennes in expressing the thoughts and actions of some of the philosophically dispersed Islamic groups, namely "liberalism" and "conservatism / fundamentalism" of religious understanding. Even in this era, there also appeared various understanding or religious practice that are considered as an anomalous. To some extent this tendency has led to internal conflicts and tensions within Muslims. In the context of academic freedom of expression also has an influence on the development of Islamic religious sciences as well as the forms and methodology of Islamic studies, although this development is also caused by the development of science and society in general. ${ }^{2}$
Islam, Departemen Agama dan Sekolah Tinggi Agama Islam (STAIN) Surakarta, pada $2-5$ November 2009.

${ }^{2}$ Masykuri Abdillah, "Kontribusi Kajian Islam Dalam Mewujudkan Masyarakat Yang Beradab", Paper di sampaikan dalam Annual Conference on Islamic Studies (ACIS), yang diselenggarakan oleh Direktorat Perguruan Tinggi Islam, Departemen Agama dan Sekolah Tinggi Agama Islam (STAIN) Surakarta, pada $2-5$ November 2009. 
This study occurs from the objective condition of Indonesia which recently rampant with issues of radicalism and fundamentalism that lead to acts of terror in the homeland, even acts of terrorism also rampant in the world. The results of the study of M Amin Abdullah affirm that it is unfair to make religion a scapegoat if there is violence in the society.

The sedds of violence that have existed intrinsically in religion do not flourish and widespread if there are no external factors that play a role. Factors that come from the outside of religious entities can ride a real political, economic, and social situations. The movement of "fundamentalism" which is commonly mentioned included in this issue. Karen Armstrong called the movement of religious fundamentalism as a "highly political spirituality" (a very weighty religious power of politic). ${ }^{3}$

However, this Islamic study at least provide the signs for the experts of Islamic studies, especially ushul fiqih expert can deepen the ijtihad paradigm of Islamic Fiqh in answering the dynamics of changing times affect the deviant behavior of religious life. Therefore, a comprehensive Islamic Fiqh Ijtihad paradigm is needed to answer

${ }^{3} \mathrm{M}$ Amin Abdullah, Dari Fundamentalism Ke Islamism : Asal Usul, Perkembangan Dan Penyebarannya, http://aminabd.wordpress.com/2010/12/14/darifundamentalism-ke-islamism-asal-usulperkembangan-dan-penyebarannya, diakses 6 Desember 2011. the empirical conditions so that the idealism of Islamic Fiqh teaching which aims to realize the benefit of human life can be realized.

Comprehensive Islamic Fiqh Ijtihad Paradigm is as an alternative solution in answering the reality of Muslims who are experiencing a contradiction between factual reality experienced by the ideals of Islamic Fiqh teaching. In addition, historically, the majority of Muslims in this country have an important role in realizing the public good, so that the Islamic Fiqh pradigma is very necessary to contribute in the development of peaceful, civilized and progressive Indonesian humanity.

The Islamic Fiqh Ijtihad paradigm is aimed to research and analyze normative Islamic fiqh studies such as' ulum al-Quran, 'ulum al-Hadith,' ulum al-'aqaid and 'ulum al-trarikh al-tasyri', and within limits - in certain limits, other sciences are used to enrich the science of this Fiqh. In addition, the paradigm of the study of fiqh is also accompanied by the rationalization of Islamic Fiqh and its context with the development of society. Therefore, the paradigm of Islamic fiqh is enriched with the perception of the social scienceshumanities. Paradigm of these sciences is used as auxiliary science to deepen and enrich the understanding of the teachings of Fiqh. Thus, Fiqh scientific scholars 
generated can provide solutions to the actual problems of mankind. In addition, the paradigm of Islamic fiqh is also conducted by integrating the scientific, rational, critical and analytical studies, although in certain level, it is not fully feasible because there are teachings of fiqh that are absolutely difficult to be criticized and rationalized. ${ }^{4}$

The theoretical framework of this study uses the thought of Masykuri Abdillah, (et.al), entitled "Formalisasi Syari'at Islam di Indonesia Sebuah Pergulatan Yang Tak Pernah Tuntas" as quoted by Labib Muttaqin in his article entitled "Positifisasi Hukum Islam dan Formalisasi Syari'ah Ditinjau Dari Teori Otoritarianisme Khaled Abou El-Fadl", Firstly, the ijtihad paradigm that want to apply Islamic teachings comprehensively (kaffah), both aqidah, syari'ah and moral ethics. Secondly, the ijtihad paradigm that aims to apply Islamic moral faith and ethics in social life. Thirdly, the ijtihad paradigm which aims to implement shari'ah in addition to aqidah and moral ethics or at least its

\footnotetext{
${ }^{4}$ Masykuri Abdillah, "Kontribusi Kajian Islam Dalam Mewujudkan Masyarakat Yang Beradab", Paper di sampaikan dalam Annual Conference on Islamic Studies (ACIS), yang diselenggarakan oleh Direktorat Perguruan Tinggi Islam, Departemen Agama dan Sekolah Tinggi Agama Islam (STAIN) Surakarta, pada $2-5$ November 2009.
}

principles are integrated into the national system. $^{5}$

\section{The Problem of Nation and State Life}

Indonesia is a pluralistic society. Pluralism requires an openness in attitude and behavior, therefore, there should be no egoism and exclusiveness in the order of life of society because the egoism and the exclusiveness of the community which then added to the legal norms of fiqh will further reinforce the attitude and behavior that might lead to radical and extreme actions. Especially in the era of reformation, the condition of society that is not deeply religious follow the radical and extreme religious sect (puritan stream), so that his action is contrary to the substance of religion that he embraces.

In this reform era also emerging puritan streams (salafi) that are intolerant of existing religious practices, although religious practice is actually still in the form of disputable problems (khilafiyyah problems). Even religious radicalism in a very violent form has also taken place in this country, which has reached its peak with the 2002 Bali bombing and Marriott Marriot Hotel bombings in 2004 and also in the last few months of July 2009. This inhumane event is also based on the distorted understanding of religious

${ }^{5}$ Labib Muttaqin, "Positifisasi Hukum Islam dan Formalisasi Syari'ah Ditinjau Dari Teori Otoritarianisme Khaled Abou El-Fadl”, dalam Jurnal al-Ihkâm, Vol. 11 No.1 Juni 2016, hlm. 78. 
teachings, especially about the concept of jihad which is defined as a war against a group considered as the enemy, and the concept of amr ma'ruf nahy munkar which is done through violence. This understanding is not originally from within the country, it is influenced by transnational movements, both radical "radical" and "salafi" groups or radical "ikhawani". This group is now still trying to spread their understanding and recruit a number of people to become their members. With the generally low educational and economic background of the people and their limited religious understanding, it may be that some of them are interested in becoming a member of that radical group. ${ }^{6}$

Meanwhile, the condition of society idealized by the people and the nation of Indonesia is actually a diverse society and nation in a peaceful atmosphere, mutual respect, tolerance and harmony. Indonesian nation should be proud to have Pancasila as an ideology that able to bind the large and diverse nation. Pancasila has become a nationalaccepted consensus to all groups, and community in Indonesia. All classes of Islam, Christian, Catholic, Hindu and Buddhist groups from the very beginning of its foundation have accepted the existence of

\footnotetext{
${ }^{6}$ Masykuri Abdillah, "Kontribusi Kajian Islam Dalam Mewujudkan Masyarakat Yang Beradab", Paper di sampaikan dalam Annual Conference on Islamic Studies (ACIS), yang diselenggarakan oleh Direktorat Perguruan Tinggi Islam, Departemen Agama dan Sekolah Tinggi Agama Islam (STAIN) Surakarta, pada $2-5$ November 2009.
}

Pancasila as the state ideology. Similarly, various ethnic, tribal, linguistic and class united to fight for and maintain Pancasila. Therefore, Pancasila as the foundation of the state has become the unifying nation as well as the leading leitstar that dynamically guide the nation in achieving its goal, which is a just and prosperous society. ${ }^{7}$

The life of the Indonesian nation will be stronger, if all components of the nation, beside understanding and implementing Pancasila, also consistently maintain the other major aspects, namely the 1945 Constitution of the Republic of Indonesia, the Unitary State of the Republic of Indonesia and Bhinneka Tunggal Ika, as the Four Pillars of Life of the Nation and State. Thus, the future struggle is to maintain Pancasila as the ideology and the basis of the state, the 1945 Constitution of the State of the Republic of Indonesia as a constitutional foundation, the Unitary State of the Republic of Indonesia as a form of state and unifier of the nation, and Bhinneka Tunggal Ika as the motto of the state which become the base to unite in plurality. ${ }^{8}$

The Four Pillars of National and State Life should be thanked and sustained by appreciating the pluralism that has been

${ }^{7}$ Pimpinan MPR dan Tim Kerja Sosialisasi MPR Periode 2009-2014, Empat Pilar Kehidupan Berbangsa dan Bernegara, Sekretariat Jenderal MPR-RI, 2012, hlm. 12.

${ }^{8}$ Pimpinan MPR dan Tim Kerja Sosialisasi MPR Periode 2009-2014, Empat Pilar Kehidupan Berbangsa dan Bernegara, Sekretariat Jenderal MPR-RI, 2012, hlm. 12-13. 
running well and dynamic along with the ingrained noble tradition of a nation up to now. Beside that, all religions contribute to national integration through its teachings that emphasize justice, compassion, unity, brotherhood, respect, and togetherness. Therefore, the next major subject is the fiqh ijtihad paradigm that becomes the reference in the life order of Indonesian Muslim society as the majority. The majority problem should not only providing the support and benefit from the implementation of Islamic jurisprudence values for Muslims, but also non-Muslims. This is a problem nowdays, Muslims are often not intact in reading the main message of fiqh which is actually build general welfare for all humanity. Moreover, the ijtihad textualconservative jurisprudence paradigm has provided a political and exclusive direction such as only having an interest in establishing an Islamic state, but not paying attention to the substance aspect of the application of Islamic jurisprudence itself.

\section{Fiqh Textual-conservative Ijtihad Paradigm}

The fiqh textual-conservative ijtihad paradigm is the dominant discourse that dominates most Muslims, so this kind of paradigm of ijtihad is easy to find in the understanding of the scriptures. In the science of the Qur'an, this paradigm of ijtihad is known as the term munasabah alverse. On the one hand, ijtihad which correlates between one verse with another verse or hadith with another hadith became one of the most desirable ijtihad paradigms of the past, but today is believed to be facing many obstacles because the understanding of the verse or legal passage has not been correlated with the empirical conditions faced by mankind. Thus, the paradigm of ijtihad of the textual-conservative fiqh is the paradigm of understanding of the nasal laws of the fiqh is not adequate, because there has been no deep effort to contextualize, sometimes it requires historic analysishermeneutis or psychological analysis. ${ }^{9}$

The terms or vocabulary in the holy book of al-Qur'an or the Prophet's Hadith, are usually understood unilaterally by various stakeholders of social, political, economic, and social interest groups. Among others can be taken example, such as Jahiliyyah (Jahiliyyah al-asr alhadith), Khalifah (popularized by the system of khilafah government), Kufr (becoming al-takfir wa alhijrah), wadhribu hunna wahjuru hunna (gender equity), and so on. Scriptural-textual understanding is easy to form an apologetic and exclusive social attitude. In the arena and struggle of the social world it is only natural that other groups

\footnotetext{
${ }^{9} \mathrm{M}$ Amin Abdullah, Dari Fundamentalism Ke Islamism : Asal Usul, Perkembangan Dan Penyebarannya, http://aminabd.wordpress.com/2010/12/14/darifundamentalism-ke-islamism-asal-usulperkembangan-dan-penyebarannya, diakses 6 Desember 2011.
} 
disagree with our views, criticize, disagree, give critical notes to the lifestyles, views, beliefs, and actions we consider unilaterally correct. When there are other people or groups, especially if the person or group is a follower of another religion, who criticizes or expresses their disapproval, then our social instincts will spontaneously refuse, at least want to defend themselves, hold firmly their ideas, beliefs and opinions us without having to be thoroughly researched and tested first. Often, when our arguments and positions are weak and a bit urgent, we also need the backing of scriptures that we understand instantly, ready to eat and ready to use, so that our position and argument is more legitimate and authoritative (charismatic). ${ }^{10}$

In this case, $\mathrm{M}$ Amin Abdullah argues that in social and religious conditions, efforts to build a deep and dialogical understanding will be difficult to obtain between internal groups of religions, especially between religions, if the paradigm of ijtihad fiqih used is textual-conservative. In other words, "compromise", "consensus" and "negotiation" efforts will not be achieved, because critical rational efforts are hegemonized by the power of interpretation of individual or group interests (religious, ethnic, racial, religious organization).

\footnotetext{
${ }^{10} \mathrm{M}$ Amin Abdullah, Dari Fundamentalism Ke Islamism : Asal Usul, Perkembangan Dan Penyebarannya, http://aminabd.wordpress.com/2010/12/14/darifundamentalism-ke-islamism-asal-usulperkembangan-dan-penyebarannya, diakses 6 Desember 2011.
}

Meanwhile, compromise and consensus are important keywords in building a pluralistic, multi-religious and multicultural society. ${ }^{11}$

Due to the urgency of the need to reinforce self-identity and group, a fast and easy scriptural-religious understanding can be held up, two sociological keywords are easily spelled out to mean "hypocrisy", inconsistencies, weaknesses of faith and ultimately "disbelief ". What a difference theological view and sociological view in this case. Of course, the literal-scriptural model of theological approach can help lead to a position of empowerment, affirmation and affirmation of the group's identity and group, but at the same time it also indicates how "poor" and "fragile" such patterns of understanding it is against the existence of others. Such positions and insights are not confined to religious groups but also to other non-religious groups. It may be argued that the unexpected consequence of the literal-scriptural understanding of the scriptures is the weakness of one's and clerical's view of the existence of other groups outside of themselves and their group. Let's not think of proexistence with other group people, at the level of coexistence alone is very difficult to obtain. ${ }^{12}$

\footnotetext{
${ }^{11} \mathrm{M}$ Amin Abdullah, Dari Fundamentalism Ke Islamism : Asal Usul, Perkembangan Dan Penyebarannya, http://aminabd.wordpress.com/2010/12/14/darifundamentalism-ke-islamism-asal-usulperkembangan-dan-penyebarannya, diakses 6 Desember 2011.

${ }^{12} \mathrm{M}$ Amin Abdullah, Dari Fundamentalism Ke Islamism : Asal Usul, Perkembangan Dan Penyebarannya, http://aminabd.wordpress.com/2010/12/14/darifundamentalism-ke-islamism-asal-usul-
} 
History proves that the textualconservative paradigm of Islamic jurisprudence has given rise to difficulties in opening up to differences, even the exclusive theology of Islam has also made a real contribution in the formation of radicalism and religious extremism in the manner of Abdurahman bin Muljam who killed Ali's Companion because of fanaticism and narrowness in understanding the teachings of Islam, so easily mengkafirkan someone who does not understand or a flow. Likewise in social life, the attitude of exclusiveness also contributes to and support for the behavior of fanaticism and sectarianism. Further M Amin Abdullah explained:

Seeds, roots, very early stages and the earliest form of "violence" are religiously literate-scriptural, and exclusive and apologetic social attitudes. It is not wrong if the "ilmu kalam" in the ulumu ul-admin study that is still continued today is defined as the building of the science of the divinity of Islam which is meant to "reject the argument of the belief system adopted by others." Up to now there is no real problem. We also know that the affirmation and affirmation of self-identity, and moreover the identity of the group more and more the identity of denominations must be built on a solid foundation, immovable in any way. If necessary by all means

perkembangan-dan-penyebarannya, diakses 6 Desember 2011. deemed reasonable and still within the limits can be socially accountable. All social entities, moreover, religious entities will defence the mechanism if their identity and groups are disturbed and disturbed by criticism, let alone attacks from other groups. If not then the essence of identity and group will fade. ${ }^{13}$

In the study of Abu Hapsin, entitled "Islam and Budaya local: Tensions between Problem Approach and Local Wisdom of Java Society", at 10th Annual Conference on Islamic Studies (ACIS), it was proposed that efforts to produce Islamic (fiqh) teachings with character which is contextual and prolongive is very difficult to achieve if only relying on the conventional / textualconservative paradigm fiqhiyyah, namely the formalistic paradigm in the study of fiqh can be seen from the pattern istinbath law that emphasizes the linguistic aspects, while the paradigm ijtihad fiqih through the rules of language will trapped in the form of birth (exoterik) of the nas, so the result of fiqh law produced only prioritize the formalistic aspects, rigid and often encounter conflict when dealing with the interests of local culture. Similarly Amir Syarifuddin argued that in ijtihad fiqih law, there is qiyas

\footnotetext{
${ }^{13} \mathrm{M}$ Amin Abdullah, Dari Fundamentalism Ke Islamism : Asal Usul, Perkembangan Dan Penyebarannya, http://aminabd.wordpress.com/2010/12/14/darifundamentalism-ke-islamism-asal-usulperkembangan-dan-penyebarannya, diakses 6 Desember 2011.
} 
method that makes the birth form of the nas as a foundation in doing ijtihad and the application of the law of fiqh. ${ }^{14}$ The orientation of the implementation of textualconservative jurisprudence is more on legal issues that are useful for Muslims and is political, whereas the application of fiqh should be useful for public welfare, not only for Muslims, but also for non-Muslims in accordance with the principles of jurisprudence which is rahmatan lil alamin.

\section{Towards a Contextual-Economics Ijtihad Fiqh Paradigm}

Significance of ijtihad fiqh (Islam) Contextual-Progressive needs to be done because Islam is generally a religion born out of dialectics between Allah's revelation and human interest. This can be explored from a number of legal passages that deal directly with local Arabic issues although they may have universal message values, so this condition requires Muslims to study to explore the universal values of jurisprudence from the Arab locality tradition if nas it is locality. However, it does not mean that the pure Islamic fiqh is influenced by the tradition of the locality of Arab society, but here there is a dialectic between the message (wahyu) of Allah and the human interest, so that if it is not intact read the source of the law, it will be

${ }^{14} \mathrm{Abu}$ Hapsin, "Islam dan Budaya Lokal: Ketegangan antara Problem Pendekatan dan Kearifan Lokal Masyarakat Jawa", Annual Conference on Islamic Studies, (ACIS) Ke - 10, Banjarmasin, 1 - 4 November 2010, hlm. 861-862; Amin Syarifuddin, Ushul Fiqh, Jilid I, (Jakarta: Kecana, Prenada Media Group, 2008), hlm. 195-197. trapped in legal formalities that escape from maqashid. Thus, the fiqh of Islam has essentially contributed to a more civilized and more advanced civil order of life in those days with changes despite gradual. The paradigm of ijtihad fiqh which emphasizes the aspect of the benefit that is then the development and application of the law of fiqh is built on the rules of phasing (al-tadrij fi al-taysri ') into a valuable way of picnic and work. In the present context it is also used to analyze the legal problems of polygamy within the figh, so that by socio-historical analysis it brings up a legal opinion that the restriction of the four wives is not the end of tasyri ', but the early stages of the application of taysri' the ultimate goal is the fa rahidah, ie couples husband in fiqih idealism is monogamy, not polygamy. Therefore, the demands of the circumstances facing the society should be a consideration in the development and application of the law of jurisprudence. The research that has been done by Khalil Abdul Karim (2003), an Egyptian thinker, shows how well Islam accommodates local culture to be used as part of religious doctrine. Long before Hasanuddin Hashmi (1989) has also undertaken the same research although focusing more on legal issues. From both studies it can be concluded that the Qur'an and the ijtihad of the Prophet Muhammad. not erasing all cultures that have taken root in the life of the Arabs. Instead, acculturation and inculturation with the local culture make it possible for inclusive community acceptance of Islamic (law, pen) Islam. ${ }^{15}$

\footnotetext{
${ }^{15} \mathrm{Abu}$ Hapsin, "Islam dan Budaya Lokal: Ketegangan antara Problem Pendekatan dan Kearifan Lokal Masyarakat Jawa", Annual Conference on Islamic Studies, (ACIS) Ke - 10, Banjarmasin, 1 - 4 November 2010, hlm. 860.
} 
Furthermore, in the study of ijtihad fiqh, there are two trends seen in terms of its purpose. First, the Islamic jurisprudence paradigm which aims to deepen the Islamic legal passages (tafaqquh fi al-din) for the proper use of practice in both personal life and public and state life. This goal is also a major goal of Islamic jurisprudence studies in Islamic religious colleges in Indonesia. This study is for ta'abbudi or taqarrub ila Allah. Secondly, the Islamic jurisprudence paradigm aimed not for the purposes of practice, but for academic or scientific research in the development of science discourses of fiqh in the contemporary era such as how to build harmonious relationships between nations or inter-faith. This pure scientific jihadist paradigm was originally practiced by Western oreintalists, for both colonial and missionary purposes and for the sole purpose of scholarship. However, the development of Muslim populations and the migration of Muslims to various parts of the world has resulted in a sobering study that triggers scientists to conduct overview studies on Islamic legal matters especially those related to public issues such as banking issues sharia is not only a study of Muslims but also non-Muslim researchers, even those who practice sharia banking regulations not only Muslims but also non-Muslims. Thus, although the paradigm of ijtihad is textually-conservative, certain parts are sometimes acceptable to all circles. This is acknowledged by Masykuri Abdillah in his research which states:

Nowadays, with the rapidly growing relationships between nations in the world, especially in this era of globalization, Islam is not only studied by its believers for the purpose of practice, but is also studied by other people (Islamologists) in an effort to build better international relations (mutual understanding) among the nations of the world ". The forms of study for the first purpose include: (1) understanding the teachings of Islam, either directly to the Qur'an and the Hadith or through the books written by scholars. (2) expresing Islamic thought (ijtihad result) with standard methodologies (mu'tabar) recognized by scholars in their field, ie ushul fiqh, ulum al-Quran, and ulum al-Hadith, (3) understanding the development of society for the formulation of teachings Contextual Islam, acceptable to society today and can respond to emerging issues. This kind of understanding follows the standard of understanding among scholars, both in substance and methodology, including on matters of the scholars (muttafaq 'alaih) and the disputed among them (mukhtalaf fih). Islamic studies for this purpose are more normative studies, both contained in the Qur'an and Hadith as well as the results of ijtihad of ulama, especially in the form of fiqh laws. If in the context of this objective is studied the empirical aspect (history), it is intended to take advantage of the event or make empirical facts as a consideration in ${ }_{16}$ understanding the teachings of Islam.

Meanwhile, the second paradigm of ijtihad fiqih is a type of purposive ijtihad paradigm which includes the objectives of: (1) researching and analyzing the teachings

\footnotetext{
${ }^{16}$ Masykuri Abdillah, "Kontribusi Kajian Islam Dalam Mewujudkan Masyarakat Yang Beradab", Paper di sampaikan dalam Annual Conference on Islamic Studies (ACIS), yang diselenggarakan oleh Direktorat Perguruan Tinggi Islam, Departemen Agama dan Sekolah Tinggi Agama Islam (STAIN) Surakarta, pada $2-5$ November 2009.
} 
of jurisprudence in accordance with the understandings once expressed by fuqaha 'and Muslim intellectuals, (2) researching and analyzing the incidents occurring within including the roles and functions of jurisprudence in the life of the ummah, using the social sciences-humanities approach, (3) reviewing the fuqaha's understanding of both the ultimate source and the thinking of the 'ulama. The study of Islamic fiqh is done by using the principles of social scienceshumanities as a rational-scientific study. The study of Islamic jurisprudence is not only done and developed by non-Muslim scientists (Islamologists), but also by Muslim scientists themselves. ${ }^{17}$

Muslim scholars who discuss things related to fiqh that have applied the paradigm of social sciences-humanities, even exact sciences, is Muhammad Syahrur who put forth the theory of limits (nadlariah al-hudud) in the science of ushul fiqih that has never been found by ulama ushul fiqih before, because of its ability to combine the study of ushul fiqih with exact sciences. Similarly Nasr Hamid Abu Zaid who has successfully gave birth to new studies in the field of fiqh, for example in the field of

\footnotetext{
${ }^{17}$ Masykuri Abdillah, "Kontribusi Kajian Islam Dalam Mewujudkan Masyarakat Yang Beradab", Paper di sampaikan dalam Annual Conference on Islamic Studies (ACIS), yang diselenggarakan oleh Direktorat Perguruan Tinggi Islam, Departemen Agama dan Sekolah Tinggi Agama Islam (STAIN) Surakarta, pada $2-5$ November 2009.
}

inheritance law or polygamy by using social-historical analysis. In this case, Masykuri Abdillah suggests:

Some Muslim scholars try to make critical understanding of Islam and offer the use of alternative methodologies / understandings, which differ entirely from the above standard methodology, as did Nasr Hamid Abu Zayd or Muhammad Shahrour. Incidentally these two scholars are not the background of Islamic religious knowledge, so their controversial thoughts are considered as a discourse. This rejection is in fact consistent with the philosophy of science, as Harold L. Brown put it, that "scientific knowledge of the consensus of scientific community" (scientific knowledge is the result of a consensus of the scientific community). In fact the use of standardized methodologies in normative Islamic studies with the auxiliaries of the auxiliary sciences above is able to respond to modern ideas and globalization as well as new emerging issues. ${ }^{18}$

In addition, the study of fiqh (Islam) is done by researching and deepening the phenomenon of Islamic religion that developed and occurred in the community,

\footnotetext{
${ }^{18}$ Masykuri Abdillah, "Kontribusi Kajian Islam Dalam Mewujudkan Masyarakat Yang Beradab", Paper di sampaikan dalam Annual Conference on Islamic Studies (ACIS), yang diselenggarakan oleh Direktorat Perguruan Tinggi Islam, Departemen Agama dan Sekolah Tinggi Agama Islam (STAIN) Surakarta, pada $2-5$ November 2009.
} 
for example how the system of inheritance division in the Java community, Minangkabau society, and Banjar people of South Kalimantan. In the matter of the division of the inheritance that became a tradition in the Muslim community, at least then gave birth to the study of jurisprudence and the breakthrough of ijtihad confronted by ulama ushul fiqih, for example in Banjar society, there is Sheikh Muhammad Arsyad al-Banjari, a very pious scholar of his time in the field fiqih who issue a fatwa division of inheritance according to the condition of Banjar society, "property of abstinence". ${ }^{19}$ Munawir Syadzali, especially in relation to the tradition of division of inheritance in Javanese society, then brought the necessity of reactualizing Islamic law in which there is a division of heirs which according to him should be studied in accordance with the actual development of the people who practice it.

The dynamic and progressive dynamics of the study of figh by ulama ushul fiqih or fuqaha 'is basically inseparable from the spirit of progressivecontextual ijtihad which has also been done by the Companions of the Holy Prophet who has also given an example in doing ijtihad of Islamic law in relation to the actual

${ }^{19}$ Djohan Effendi, "Islam di antara Teks dan Konteks", Paper untuk Annual Conference on Islamic Studies (ACIS) ke-10, Kementerian Agama RI di Banjarmasin tanggal 1-3 Nopember 2010, hlm. problems facing the community. One of the actual examples put forward by Abu Hapsin here is the policy of 'Umar ibn Khattab's friend on the issue of the spoils of warfare which differs from the law's policy of the time of the Holy Prophet, but it is more in the aspect of his application of the law to the empirical-state, the substance of the law. Therefore, the substance of the legal jurisprudence applied by the Prophet and 'Umar alike to realize the ultimate benefit. It is reasonable that under these circumstances the problems arising in such diverse societies are very different from the problems that arise when Muslims are still on the Arabian penisula. This is why Umar ra. many reform policies that are different from the traditions (sunnah) of the Prophet, such as the policy of distribution of spoils (ghanimah), hand-cutting reprieve, sale of slaves, even when Egypt was conquered, Umar ra. No longer giving zakat to convert when this provision is clearly arranged in certainty in al-Qur'an (Rahman, 1984: 271285). The above facts show that the human being who became the object of Shari "at, on his fitrah is an individual who has a dynamic and creative character. That is why Muhammad Sharur is right when formulating Islamic law into two bounds, namely the upper limit (hadd al-'a'la) and the lower limit (had al-adna). In these two limits humans are given the space of freedom to 
choose and determine the law in accordance with the conditions and situations. Regardless of the weaknesses of his theory, with the evidence that there are still many Qur'anic verses that still can not be categorized into the six Hadd categories, his ideas have enriched Islamic intellectual property in relation to legal interpretation methods appropriate to conditions and situations. $^{20}$

'Umar's policy is basically a part of empirical jurisprudence study because the policy is not initially initiated from the legal norms derived from the legal norms of jurisprudence which comes from the Qur'an and Sunnah, but rather reads the empirical phenomena facing society where the Umarled society needs the general welfare (almashlahah al-'ammah), so that the starting point for the development of fiqih law begins with the interests of the society which then abstracts its normative basis from the source of the Qur'an and Sunnah. By borrowing Masykuri Abdillah's thought, the paradigm of the study is part of the empirically historical empirical study of Islamic jurisprudence, so the method of study is the social and historical research method used to discuss the jurisprudence of

\footnotetext{
${ }^{20} \mathrm{Abu}$ Hapsin, "Islam dan Budaya Lokal: Ketegangan antara Problem Pendekatan dan Kearifan Lokal Masyarakat Jawa", Annual Conference on Islamic Studies, (ACIS) Ke - 10, Banjarmasin, 1 - 4 November 2010, hlm. 860-861.
}

fiqh. Because the subject in the study of this empirical condition is not the substance of Islamic jurisprudence itself, this study is commonly mentioned by philological, historic or study (fiqh) studies of Islam through sociological, anthropological, historical, phenomenological, or philological approaches. Classical Islamologists generally use a philological and historical approach in the study of theology, its militia Approaches to Islam in Religion Studies edited by Richard C. Martin, and Approaches to the Study of religion edited by Peter Conolly. ${ }^{21}$

Paradigm ijtihad fiqh contentprogressive try to build the Indonesian people who are able to practice the jurisprudence of fiqh law, that is how the values of jurisprudence that can be applied in social life that is characterized by the attitude of mutual respect, tolerance and inclusive as embraced by the paradigm the second ijtihad, in addition also in the formal legal, society that is able to translate the legal values of jurisprudence in national law legislation. How can the Indonesian society transform the law in its metaphysical form as an idea to law into its more concrete and

\footnotetext{
${ }^{21}$ Masykuri Abdillah, "Kontribusi Kajian Islam Dalam Mewujudkan Masyarakat Yang Beradab", Paper di sampaikan dalam Annual Conference on Islamic Studies (ACIS), yang diselenggarakan oleh Direktorat Perguruan Tinggi Islam, Departemen Agama dan Sekolah Tinggi Agama Islam (STAIN) Surakarta, pada $2-5$ November 2009.
} 
listened forms there are senses. Through the process of positiveization, the fiqih law which was originally a norm of justice, morality and ethics that has not had the force to force and bind into law when it became a positive written law, then he has the force that forces one to obey as the third ijtihad paradigm. $^{22}$

Especially if traced the history of the spread of Islam in the archipelago, then found that Islam is spread by peaceful and aktulturatif which then it has given its own color and character where the teachings of Islam especially in the field of fiqih put forward the aspect of harmony and tolerance and accommodative to the cultural development of a diverse Indonesian society. Therefore, although the law of jurisprudence has become a regulation of national law, but there is no friction and opposition in society as Law No. 1 of 1974 on Marriage and the Compilation of Islamic law related to the codification of family law in Islam, including the rules inheritance, Law of the Republic of Indonesia Number 38 Year 1999 on Zakat Management, Law of the Republic of Indonesia Number 41 Year 2004 regarding Waqf, Law of the Republic of Indonesia Number 13 of 2008 Amendment to Law Number 17 of 1999 on

\footnotetext{
${ }^{22}$ Labib Muttaqin, "Positifisasi Hukum Islam dan Formalisasi Syari'ah Ditinjau Dari Teori Otoritarianisme Khaled Abou El-Fadl", dalam Jurnal al-Ihkâm, Vol. 11 No.1 Juni 2016, hlm. 78.
}

the Implementation of Hajj, and the Law of the Republic of Indonesia Number 21 Year 2008 on Syariah Banking. ${ }^{23}$

In the present context, the progressive paradigm of ijtihad fiqh is needed to develop the dynamics of human life as a whole, especially the issue of jurisprudence which deals with public interests such as economic problems. The application of jurisprudence in the economic field has affected welfare not only for Muslims, but also for non-Muslims. The indication is the enactment of the Law of the Republic of Indonesia Number 21 Year 2008 on Sharia Banking, all nationals from any origin can enjoy sharia banking services. This phenomenon has been proven from the results of a study by Mohamad Nur Yasin, entitled "The Pluralism of Islamic Economic Law: Dialectic of Moslem and non-Moslem in the Development of Sharia Banking in Indonesia", in the Journal of Indonesian Islam, Volume 10, Number 01, June 2016 which proves that Islamic banking or Islamic business units have made a real contribution in supporting the welfare of society, not only Muslims but also nonMuslims. Simple indications are those who

\footnotetext{
${ }^{23}$ Labib Muttaqin, "Positifisasi Hukum Islam dan Formalisasi Syari'ah Ditinjau Dari Teori Otoritarianisme Khaled Abou El-Fadl”, dalam Jurnal al-Ihkâm, Vol. 11 No.1 Juni 2016, hlm. 80.
} 
are sharia banking customers as well as those from non-Muslims. ${ }^{24}$

With the rule of Law of the Republic of Indonesia Number 38 Year 1999 on Zakat Management, then in the elaboration of the zakat problem, the MUI issued the advices of Indonesian Ulama Council Fatwa Number 3 of 2003 concerning Income Zakat which states that "income" is any income such as salary, honorarium, wages, services, etc. obtained through halal methods, both routine such as state officials, employees, non-routine occupation such as doctors, lawyers, consultants, etc, as well as income derived from other free work ". Based on the description, the MUI Fatwa decided that "the law of all forms of halal income must be issued zakat on condition that it has reached nishab in one year, which is 85 grams of gold". With the decision of the MUI, the next regulation then elaborated the problem of the scope of zakat, namely in the Law of the Republic of Indonesia Number 23 of 2011 concerning Management of Zakat which mentions in Article 4, namely:

(1) Zakat includes mal zakat and fitrah zakat. (2) Mal Zakat as referred in paragraph (1) includes: a. gold, silver and other precious metals; b. money and other securities; c. commerce; d.

${ }^{24}$ Mohamad Nur Yasin, "The Pluralism of Islamic Economic Law: Dialectic of Moslem and non-Moslem in the Development of Sharia Banking in Indonesia", Journal of Indonesian Islam, Volume 10, Number 01, June 2016, hlm. 114-117. agriculture, plantation and forestry; e. livestock and fisheries f. mining; g. industry; h. income and services; and i. rikaz. (3) Mal Zakat as referred in paragraph (2) is a property owned by an individual or business entity. (4) The requirements and procedures for calculating zakat and zakat fitrah are carried out in accordance with Islamic law.

Law of the Republic of Indonesia Number 23 of 2011 concerning Management of Zakat is a change from Law Number 38 of 1999 concerning Management of Zakat (State Gazette of the Republic of Indonesia of 1999 Number 164; Supplement to the State Gazette of the Republic of Indonesia Number 3885) which is declared revoked and no longer valid since the enactment of the Law of the Republic of Indonesia Number 23 of 2011 where in its consideration stated that "Law Number 38 of 1999 concerning Management of Zakat is not in accordance with the development of legal needs in society so that it needs to be replaced".

The principle of the purpose of the Law of the Republic of Indonesia Number 23 of 2011 concerning the Management of Zakat is to ensure the citizens carry out their religion and worship according to their religion, while zakat is an obligation for Muslims who are able to comply with the teachings of Islamic law. The need is to improve the justice and community welfare. 
The results of Yoghi Citra Pratama's research entitled "The Role of Zakat in Poverty Reduction: A Case Study of Productive Zakat Programs in the National Zakat Agency", in The Journal of Tauhidinomics stated:

Although the zakat funds collected are still very small, but have a real impact in efforts to alleviate poverty through productive zakat programs and zakat is an effective financial instrument in the problem of the capital of the poor people. This can be seen from the Headcount Ratio which decreased from 0.8 to 0.5 . The poverty depth index also experienced a decline where the poverty gap decreased from Rp. 547,843 to Rp. 210,020. Likewise, the value of I which has decreased from 0.44 to 0.17 which shows a decrease in the income gap. The value of the Sen index also decreased from 0.50 to 0.24. Similarly, the FGT index number. The value of the FGT index also decreased from 0.27 to 0.10 . This shows that zakat is the right instrument in empowering the poor people. $^{25}$

Thus, the benefits of zakat management / sharia business management unit are of course not only useful for certain circles, but also all the nation's children will benefit from the economic equality of this zakat system, so that justice and welfare of the nation's children can be realized. The

${ }^{25}$ Yoghi Citra Pratama, "Peran Zakat Dalam Penanggulangan Kemiskinan: Studi Kasus Program Zakat Produktif Pada Badan Amil Zakat Nasional", The Journal of Tauhidinomics Vol. 1 No. 1 (2015), hlm. 103.
MUI Fatwa decision is one example of how progressive-economic jurisprudence can contribute to the dynamics of national law institutionalization in order to realize general welfare throughout Indonesia.

Thus, the paradigm ijtihad fiqhprogressive context is an urgent need to realize the paradigm of development and the enforcement of the law of jurisprudence in both social and state level. Paradigm ijtihad is also at once rejected the first paradigm of ijtihad who want to apply the totality of Islamic sharia in the form of state ideology by replacing Pancasila with Islamic sharia ideology. This first ijtihad paradigm is incompatible with the contextualprogressive Islamic ijtihad fiqh paradigm offered in this study because it is normatively of no basis, and historically the Prophet himself had never established a Medina state that was ideology of Islamic law but instead was based on the Medina Charter which mengekomodir all classes, tribes and races that live and thrive in the country of Medina. ${ }^{26}$

${ }^{26}$ Lihat, Ahmad Sukardja, Piagam Madinah dan Undang-Undang Dasar NRI 1945; Kajian Perbandingan tentang Dasar Hidup Bersama dalam Masyarakat Majemuk, (Jakarta: Sinar Grafika, 2014); KH Said Aqil Siraj, Islam Sumber Inspirasi Budaya Nusantara Menuju Masyarakat Mutamaddin, (Jakarta: LTNU, 2014). 


\section{Closing}

In building the ideal Indonesian society and state, the paradigm of progressive fiqih ijtihad should be used to lay the universal values in a tolerant, harmonious and peaceful social order of social life as embraced in the second paradigm of ijtihad, and also seek to explore the legal values of jurisprudence to be transformed into legitimate state life, the transform of legal values of jurisprudence into national law which is expected not only to benefit Muslims but also in certain aspects can also provide benefits to nonMuslims as the implementation of Islamic banking that is not only beneficial to the Muslim community, but also beneficial to non-Muslim communities. One of important aspect that is felt by all children of the Indonesian people is the implementation of Islamic banking / sharia business units / zakat which are not only useful and provide welfare impacts for Muslims, but also for non-Muslims. It cannot be separated from the influence of the progressive-economic ijtihad paradigm which has provided an alternative example that the application of Islamic law / fiqh can actually benefit for all humanity and all Indonesian citizens.

\section{References}

Abdillah, Masykuri, "Kontribusi Kajian Islam Dalam Mewujudkan
Masyarakat Yang Beradab", Paper di sampaikan dalam Annual Conference on Islamic Studies (ACIS), yang diselenggarakan oleh Direktorat Perguruan Tinggi Islam, Departemen Agama dan Sekolah Tinggi Agama Islam (STAIN) Surakarta, pada 2 - 5 November 2009.

Abdullah, M Amin, Dari Fundamentalism Ke Islamism : Asal Usul, Perkembangan

Dan Penyebarannya, http://aminabd.wordpress.com/2 010/12/14/dari-fundamentalismke-islamism-asal-usulperkembangan-danpenyebarannya, diakses 6 Desember 2011.

Effendi, Djohan, "Islam di antara Teks dan Konteks", Paper untuk Annual Conference on Islamic Studies (ACIS) ke-10, Kementerian Agama RI di Banjarmasin tanggal 1-3 Nopember 2010, hlm.

Hapsin, Abu, "Islam dan Budaya Lokal: Ketegangan antara Problem Pendekatan dan Kearifan Lokal Masyarakat Jawa", Annual Conference on Islamic Studies, (ACIS) $\mathrm{Ke}-10$, Banjarmasin, 1 - 4 November 2010.

Muttaqin, Labib, "Positifisasi Hukum Islam dan Formalisasi Syari'ah Ditinjau Dari Teori Otoritarianisme Khaled Abou El-Fadl", dalam Jurnal alIhkâm, Vol. 11 No.1 Juni 2016, hlm. 78 .

Muttaqin, Labib, "Positifisasi Hukum Islam dan Formalisasi Syari'ah Ditinjau Dari Teori Otoritarianisme Khaled Abou El-Fadl", dalam Jurnal alIhkâm, Vol. 11 No.1 Juni 2016. 
Pimpinan MPR dan Tim Kerja Sosialisasi MPR Periode 2009-2014, Empat Pilar Kehidupan Berbangsa dan Bernegara, Sekretariat Jenderal MPR-RI, 2012.

Pratama, Yoghi Citra, "Peran Zakat Dalam Penanggulangan Kemiskinan: Studi Kasus Program Zakat Produktif Pada Badan Amil Zakat Nasional", The Journal of Tauhidinomics Vol. 1 No. 1 (2015)

Siraj, KH Said Aqil, Islam Sumber Inspirasi Budaya Nusantara Menuju Masyarakat Mutamaddin, Jakarta: LTNU, 2014.

Sukardja, Ahmad, Piagam Madinah dan Undang-Undang Dasar NRI 1945: Kajian Perbandingan tentang Dasar Hidup Bersama dalam Masyarakat Majemuk, Jakarta: Sinar Grafika, 2014.

Syarifuddin, Amin, Ushul Fiqh, Jilid I, Jakarta: Kecana, Prenada Media Group, 2008.

Yasin, Mohamad Nur, "The Pluralism of Islamic Economic Law: Dialectic of Moslem and nonMoslem in the Development of Sharia Banking in Indonesia", Journal of Indonesian Islam, Volume 10, Number 01, June 2016. 